\title{
Urokinase Receptor Is a Multifunctional Protein: Influence of Receptor Occupancy on Macrophage Gene Expression
}

\author{
Navaneetha K. Rao, ${ }^{\star \star \$}$ Guo-Ping Shi, ${ }^{\star \$}$ and Harold A. Chapman ${ }^{* \$}$ \\ ${ }^{*}$ Division of Biological Sciences, and ${ }^{\ddagger}$ Physiology Program, Harvard School of Public Health, and ${ }^{\S}$ the Department of Medicine, \\ Brigham and Women's Hospital, Boston, Massachusetts 02115
}

\begin{abstract}
Binding of urokinase to the glycolipid-anchored urokinase receptor ( $U P A R$ ) has been implicated in macrophage differentiation. However, no biochemical markers of differentiation have yet been directly linked to uPAR occupancy. As extensive changes in proteolytic profile characterize monocytic differentiation, we have examined the role of uPAR occupancy on protease expression by differentiating phagocytes. Antibodies to either urokinase or to uPAR that prevent receptor binding inhibited induction of cathepsin $B$ in cultured monocytes and both cathepsin $B$ and 92-kD gelatinase mRNA and protein in phorbol diester-stimulated myeloid cells. Mannosamine, an inhibitor of glycolipid anchor assembly, also blocked protease expression. Anti-catalytic urokinase antibodies, excess inactive urokinase, or aprotinin had no effect, indicating that receptor occupancy per se regulated protease expression. Antibodies to the integrins CD11a and CD29 or to the glycolipid-anchored proteins CD14 and CD55 also had no effect. Protease induction was independent of matrix attachment. Antibodies to urokinase or UPAR affected neither the decrease in cathepsin $G$ nor the increase in tumor necrosis factor- $\alpha$ in phorbol esterstimulated cells. These data establish that uPAR is a multifunctional receptor, not only promoting pericellular proteolysis and matrix attachment, but also effecting cysteine- and metallo-protease expression during macrophage differentiation. (J. Clin. Invest. 1995. 96:465-474.) Key words: urokinase receptor $\cdot$ macrophage $\cdot$ gene expression
\end{abstract}

\section{Introduction}

PMA treatment of the human leukemic cell lines HL-60, U937, and THP-1, arrested at various stages of development, is associ-

Address correspondence to Harold A. Chapman, M.D., Brigham and Women's Hospital, Thorn Research Bldg., Rm 703, 20 Shattuck St., Boston, MA 02115. Phone: 617-732-6074; FAX: 617-232-4623.

Received for publication 15 July 1994 and accepted in revised form 21 March 1995

1. Abbreviations used in this paper: cat $\mathrm{B}$, cathepsin $\mathrm{B} ; \mathrm{D}_{3}, 1,25$ $(\mathrm{OH})_{2}$ vitamin $\mathrm{D}_{3}$; DFP, diisopropylfluorophosphate; E-64, L-trans Epoxysuccinyl-leucylamido(4-guanido)butane; GPI, glycosylphosphatidylinositol; Y-A-CHN ${ }_{2}$, tyrosine-alanine-diazomethylketone; MA mannosamine; MMP, matrix degrading metalloprotease; PAI, plasminogen activator inhibitor; s-uPAR, soluble urokinase receptor; uPA, urokinase; uPAR, urokinase receptor.

J. Clin. Invest.

(C) The American Society for Clinical Investigation, Inc. 0021-9738/95/07/0465/10 \$2.00

Volume 96, July 1995, 465-474 ated with cessation of proliferation and acquisition of a differentiated, macrophage-like phenotype (1-3). Among the many changes in gene expression that accompany the differentiation of these cells are striking changes in the expression of proteases (4-8). These changes reflect the complex developmental control of proteases and presumably facilitate the functions of migratory progenitors and tissue macrophages. Unstimulated myeloid cells and fresh monocytes contain high levels of the serine proteases cathepsin $\mathrm{G}$ and human neutrophil elastase (HNE) $(4,9,10)$. Analogous to neutrophils, these serine proteases are stored in cytoplasmic granules and can be rapidly released in response to extracellular signals. In contrast, differentiated macrophages express little, if any, cathepsin $\mathrm{G}$ and $\mathrm{HNE}$ and are now able to express in a regulated manner metallo- and cysteineproteases $(6,7,11)$. Differentiation toward macrophages is also accompanied by increased expression of the serine protease urokinase-like plasminogen activator (uPA) and its cognate glycosylphosphatidylinositol (GPI)-anchored cell surface receptor (12-14). Urokinase binds the first of the three homologous domains of ( $\mathrm{UPAR}$ ) and efficiently converts plasminogen at the cell surface to the broad-spectrum serine protease, plasmin (15, 16). Plasmin, metalloproteases, and cysteine proteases cooperate with each other (17) to mediate the degradative functions of macrophages.

Receptor-bound uPA not only promotes pericellular proteolysis, but also, independent of its catalytic activity, promotes the adhesiveness of PMA- and cytokine-stimulated leukemic cells $(18,19)$. We have recently reported that uPA-dependent adhesion is specific for vitronectin and that the urokinase receptor itself is a high affinity receptor for vitronectin (20,21). Urokinase appears to activate this adhesive function and thus adhesion is directly related to the number of uPA-bound receptors. Adhesion is not only a marker for but also is an integral part of macrophage differentiation, as adhesion modulates the expression of cytokines (TNF $\alpha, \mathrm{CSF}-1, \mathrm{IL}-1$ ) and proto-oncogenes (c-fms, c-fos) $(22,23)$. Thus, by promoting/regulating adhesion, the UPA/uPAR interaction may also modulate the expression of potent regulators of macrophage function, and indirectly influence the expression of genes important for differentiated macrophages. Potentially, uPAR occupancy may directly transduce signals, as has been documented for some GPI-anchored proteins $(24,25)$, and influence the phenotype of macrophages. In fact, uPAR bound uPA has been demonstrated to induce cellular responses both dependent on $(26,27)$ and independent of (28-30) its catalytic activity.

The current study was undertaken to define the influence of UPAR occupancy on gene expression by differentiating phagocytes and to explore the cellular basis for such a function. We show for the first time that receptor-bound uPA can not only promote pericellular proteolysis, but can also directly influence the expression of cathepsin B (cat B) and the $92-\mathrm{kD}$ gelatinase (matrix metalloprotease [MMP-9]) mRNA and protein during 
macrophage differentiation. These results extend the cooperation seen among distinct classes of proteases at the macrophage cell surface to regulation of their gene expression.

\section{Methods}

Reagents. RPMI 1640 was obtained from GIBCO BRL (Gaithersburg, MD), FBS from Hyclone Laboratories Inc. (Logan, UT), and tissue culture ware from Falcon Laboratories (Lincoln Park, NJ). Human leukemic cell lines U937 and THP-1 were obtained from American Type Culture Collection (ATCC, Rockville, MD). Na $\left[{ }^{125} \mathrm{I}\right],\left[\alpha^{3}{ }^{32} \mathrm{P}\right] \mathrm{dATP}$, $\left[{ }^{3} \mathrm{H}\right]$ diisopropylfluorophosphate (DFP) $(4 \mathrm{Ci} / \mathrm{mM})$, anti-rabbit $\left[{ }^{125} \mathrm{I}\right]-$ IgG, and $\left[{ }^{3} \mathrm{H}\right]$ thymidine were from New England Nuclear (Boston, MA). [ $\left.{ }^{125} \mathrm{I}\right] \mathrm{JPM},\left[{ }^{125} \mathrm{I}\right]$ tyrosine-alanine-diazomethylketone ( $\left[{ }^{125} \mathrm{I}\right] \mathrm{Y}-\mathrm{A}-$ $\left.\mathrm{CHN}_{2}\right)$, recombinant human two chain-uPA, and $1,25,-(\mathrm{OH})_{2}$ vitamin $D_{3}\left(D_{3}\right)$ were kind gifts from Drs. J. Munger (Brigham and Women's Hospital, Boston, MA), S. Weiss (University of Michigan, Ann Arbor, MI), J. Henkin (Abbott Labs, Abbott Park, IL), and M. Uskokvic (Hoffmann-LaRoache Laboratories, Nutley, NJ), respectively. Recombinant human TGF $\beta$ was from Collaborative Research (Bedford, MA). Monospecific polyclonal rabbit anti-uPA which abrogates receptor binding was from Alpha-Therapeutic Corp. (Los Angeles, CA), and monoclonal anticatalytic anti-uPA (374) and polyclonal goat anti-plasminogen activator inhibitor (PAI)-1 (395G) were from American Diagnostica Inc. (Greenwich, CT), respectively. Recombinant uPAR, comprising the $\sim 16-\mathrm{kD} \mathrm{NH}_{2}$-terminal ligand-binding domain, was expressed as previously described (21). Briefly, a 452-bp $\mathrm{NH}_{2}$-terminal uPA-binding domain was obtained by EcoR1 and pst1 partial digestion of full-length uPAR cDNA. A fusion protein comprising this fragment was expressed using the pFLAG-1 ${ }^{\mathrm{TM}}$ expression system (IBI-A Kodak Co., New Haven, CT), and purified in preparative SDS-PAGE gels. Minced gel or electroeluted protein was used to raise antibodies (East Acres Biologicals, Southbridge, MA). Polyclonal antibodies to the recombinant uPAR raised in sheep and rabbits specifically recognized uPAR in Western blots of U937 cell lysates. IgG purified from sheep anti-uPAR sera blocked (in a uPA reversible manner) the adhesion of PMA-stimulated myeloid cells to plastic. mAbs (ascites fluid, $1 \mathrm{mg} / \mathrm{ml}$ total protein, $0.02 \%$ sodium azide) directed against the ligand binding domain-1 of uPAR were provided by Dr. R. F. Todd (University of Michigan, Ann Arbor, MI), as part of a panel for the $5^{\text {th }}$ International Workshop on Leucocyte Differentiation Antigens, 1993. One of these antibodies, MA13, was determined to be more effective than MA113, another member of the monoclonal panel, in blocking (in a uPA-reversible manner) the adhesion of PMA-stimulated myeloid cells to plastic, and hence was used in subsequent assays. The mAbs R2 and R4 (purified $\mathrm{IgG}, 1 \mathrm{mg} / \mathrm{ml}$ ), directed to the domains $2 / 3$ of uPAR were provided by Dr. Ebbe Ronne (Finsen Laboratories, Copenhagen, Denmark), and mAbs to CD55 (ascites fluid, $0.02 \%$ sodium azide) were provided by Dr. Charles Parker (Department of Medicine, University of Utah, Salt Lake City, UT). mAbs to CD14 (ascites fluid, $3 \mathrm{mg} / \mathrm{ml}$ protein), and various integrin molecules ( $1 \mathrm{mg} / \mathrm{ml}$ purified $\mathrm{IgG}, 0.01 \%$ sodium azide) were from Solarcare Tech (Bethlehem, PA) and Beckton Dickinson (San Jose, CA), respectively. Polyclonal anti-vitronectin antibodies were from Calbiochem Advanced Cellular Biology (La Jolla, CA). Polyclonal antibodies to cat B and MMP-9 were from Drs. R. Mason (Virginia Tech, Blacksburg, VA), and T. Pourmotabbed (University of Tennessee, Memphis, TN), respectively. Full-length MMP-9 cDNA was from Dr. S. Shapiro (Washington University, St. Louis, MO), and the 1.2-kb G3PD cDNA was from ATCC. Other chemicals including mannosamine (2-amino-2-deoxy D-mannose) and Triton X-114 were from Sigma Chemical Co. (St. Louis, MO), or Bio Rad Labs. (Hercules, CA).

Cell culture. U937 and THP-1 cells were cultured in RPMI 1640 supplemented with penicillin $(100 \mu \mathrm{g} / \mathrm{ml})$, streptomycin $(100 \mu \mathrm{g} / \mathrm{ml})$, Hepes ( $20 \mathrm{mM}, \mathrm{pH} 7.4)$, and 5-10\% FBS. THP-1 culture medium was made $48 \mu \mathrm{M}$ with 2-mercaptoethanol. Myeloid cells were induced to differentiate by adding $16 \mathrm{nM}$ PMA (1). In some experiments, $D_{3}$ was used to enhance the response of U937 cells to PMA (31). Mononuclear cells (PBMCs), isolated from heparinized $(20 \mathrm{U} / \mathrm{ml})$ venous blood $(\sim 60 \mathrm{ml})$ of healthy volunteers by Ficoll-Hypaque density separation, were cultured in RPMI 1640 containing $10 \%$ heat-inactivated heterologous human serum. All incubations were at $37^{\circ} \mathrm{C}, 5 \% \mathrm{CO}_{2}$, and cells were plated either at $10^{6} / \mathrm{ml}$ (U937 and THP-1) or $5 \times 10^{6} / \mathrm{ml}$ (PBMCs). Unless otherwise indicated, all treatments were for $24 \mathrm{~h}$ and were carried out with $100 \mu \mathrm{l}$ cells/well in 96-well microtitre plates. Cells were negative for mycoplasma as assessed by an enzyme detection kit (Mycotect; GIBCO BRL), and were greater than $95 \%$ viable as assessed by trypan blue exclusion. None of the treatments discussed below affected the viability of the cells. As JPM labeling (see below) indicated that low $\mathrm{nM}$ amounts of endotoxin inhibited the expression of active cat B in PMA-stimulated cells, all antibodies obtained either commercially or as gifts and used in cat B assays were determined to be negative for endotoxin as assessed by the limulus assay (E-Toxate kit; Sigma Chemical Co.). The R4 antibody, however, tested positive and was not used in the cat B assays. This antibody was used in the MMP-9 assay as endotoxin, if anything, increases MMP-9 expression.

Mannosamine treatment. To assess the affect of impaired GPI anchor synthesis, cells were stimulated with PMA in the presence of 10 $\mathrm{mM}$ mannosamine (MA) in regular, glucose $(2 \mathrm{~g} / \mathrm{ml})$ containing RPMI, and $10 \%$ fetal bovine serum. In some experiments cells were incubated overnight with 2 mM MA before stimulus.

Triton X-114 phase separation of membrane proteins. Temperatureinduced phase separation in Triton X-114, initially described by Bordier (32), has been used to characterize the GPI-anchored uPAR (33). To determine if impaired GPI anchor synthesis results in partitioning of uPAR into the aqueous phase, membranes obtained from U937 cells stimulated with PMA either in the presence or absence of mannosamine, were induced to undergo phase separation in Triton X-114. Membranes were obtained by ultracentrifugation of cells homogenized in a buffer containing $0.25 \mathrm{M}$ sucrose, $1 \mathrm{mM}$ EDTA, $10 \mathrm{mM}$ Tris, and a cocktail of protease inhibitors (34). Membrane pellets were extracted in a $1 \%$ Triton X-114 buffer containing $0.1 \mathrm{M}$ Tris- $\mathrm{HCl}, 10 \mathrm{mM}$ EDTA, $\mathrm{pH}$ 8.1, on ice followed by phase separation at $37^{\circ} \mathrm{C}$. The detergent-rich pellet was separated from the aqueous phase by centrifugation at room temperature, dispersed in SDS-PAGE sample buffer and analyzed by Western blotting.

Collection of conditioned medium from 293 cells. Human kidney epithelial 293 cells were transfected with a truncated, soluble version (residues 1-277) of human uPAR (s-uPAR), lacking the GPI-anchoring domain, as described elsewhere (21). These cells were maintained in DME, $10 \%$ FBS and $50 \mu \mathrm{g} / \mathrm{ml}$ hygromycin. Conditioned medium free of serum and hygromycin, collected after an overnight culture of transfected cells in DME, was demonstrated to contain soluble uPAR that retained its ability to bind uPA. Conditioned medium thus collected was selectively depleted of soluble uPAR by using pro-uPA-coated immunoplates (Maxi-sorp Nunc Immunoplates; Marsh Biomedical Products, Inc., Rochester, NY). Briefly, the wells were coated overnight at $37^{\circ} \mathrm{C}$ with $1 \mu \mathrm{g}$ pro-uPA per well $(100 \mu \mathrm{l})$. After removing unbound pro-uPA from the wells, sequential incubations ( $100 \mu \mathrm{l}$ per well) of $\sim 1 \mathrm{~h}$ each resulted in the selective depletion of s-uPAR. The effect of normal and depleted conditioned media on PMA-stimulated U937 cells was studied by replacing RPMI with various concentrations (10-80\%) of these media. Conditioned media obtained from nontransfected 293 cells and from 293 cells transfected with an irrelevant gene (antisense cathepsin D) were used as controls.

A similar approach was followed to selectively deplete the rabbit polyclonal anti-uPA antibody. The monoclonal anti-uPAR antibody, MA13, was selectively depleted using s-uPAR-conditioned mediumcoated plates.

Flow cytometry. An estimate of the extent of UPAR occupancy by uPA was obtained by using flow cytometry essentially as previously described (35). Briefly, unstimulated and PMA-stimulated (24 h) U937 cells were resuspended in RPMI containing $2.5 \%$ FBS, and were incubated with the primary anticatalytic antibody (1:50) on ice for $30 \mathrm{~min}$. In some experiments cells were either incubated with $100 \mathrm{nM}$ active 
uPA or acid-washed (19) before incubation with the primary antibody. After washing, cells were exposed to FITC-conjugated anti-mouse $\left.\mathrm{F}(\mathrm{ab})_{2}\right)_{2}$ fragments for $30 \mathrm{~min}$ on ice. The mean fluorescence of live cells was determined by using an Ortho Flow Cytometry 2151 system. Nonspecific fluorescence was obtained by using nonimmune mouse IgG as the primary antibody.

DFP-inactivation of UPA. UPA was inactivated with $5 \mathrm{mM}$ DFP at room temperature for $1 \mathrm{~h}$ as previously described $(18,19)$. Protein concentration of DFP-uPA was determined by $\mathrm{A}_{280}$ and confirmed by ELISA and total protein analysis. DFP treatment resulted in undetectable catalytic activity as measured by using a plasminogen-dependent fluorometric assay previously described (19).

Assay for cysteine proteases. Expression of active lysosomal cysteine proteases was assessed by using class-specific active site probes. JPM, an analogue of the cysteine protease-specific inhibitor, L-transEpoxysuccinyl-leucylamido(4-guanido)butane (E-64), was iodinated using the Iodagen protocol previously described (36). For labeling, adherent and nonadherent cells were washed, pooled, and lysed by two cycles of freeze-thaw in a buffer containing $1 \%$ Triton X-100, $20 \mathrm{mM}$ sodium acetate, $1 \mathrm{mM}$ EDTA, $\mathrm{pH} 5.5$, and treated with saturating amounts of $\left[{ }^{125} \mathrm{I}\right] \mathrm{JPM}$ in presence of $3 \mathrm{mM}$ cysteine, for $1 \mathrm{~h}$ at $37^{\circ} \mathrm{C}$. The lysates were then mixed 1:1 with $2 \times$ reduced sample buffer and subjected to SDS-PAGE (10\%), followed by autoradiography. Excess cold E-64 blocked labeling by [ $\left.{ }^{125} \mathrm{I}\right] \mathrm{JPM}$, indicating the specificity of the probe for cysteine proteases. In some experiments adherent and nonadherent cells were washed, pooled, and intact cells labeled by incubation with the cell-permeable active site probe, $\left[{ }^{125} \mathrm{I}\right] \mathrm{Y}-\mathrm{A}-\mathrm{CHN}_{2}$ for 1 $\mathrm{h}$ at $37^{\circ} \mathrm{C}, 5 \% \mathrm{CO}_{2}$. Cells were separated from the supernatant fluid and lysed in reduced sample buffer, subjected to SDS-PAGE and autoradiography. Extent of cat $B$ induction was assessed by scanning densitometry using a CCD camera and NIH Image analysis software (MacIntosh II). In some instances cysteine protease activity was also assessed by using the fluorogenic dipeptide, Z-F-R-NMec, as substrate (6).

Assay for metalloproteases. Secretion of metalloproteases by PMAstimulated myeloid cells was assessed by Western blotting. Cell-free culture media were mixed with $2 \times$ reduced sample buffer, boiled for $10 \mathrm{~min}$, and subjected to SDS-PAGE ( $8 \%$ ), followed by electrotransfer onto nitrocellulose. Nonspecific binding was blocked with $5 \%$ (wt/vol) nonfat dry milk powder and the membranes were sequentially treated with rabbit anti-MMP9 and goat anti-rabbit [ $\left.{ }^{125} \mathrm{I}\right] \mathrm{IgG}$. After extensive washing, the membrane was subjected to autoradiography. The extent of MMP-9 induction was determined by scanning densitometry. In some experiments secretion of metalloproteases into the culture medium was assessed by zymography in $8 \%$ nonreducing SDS-PAGE containing $0.15 \%$ gelatin.

Assay for serine proteases. Expression of active serine proteases was assessed by using the irreversible, class-specific inhibitor, DFP. U937 cells were cultured in 24-well plates at $1 \times 10^{6}$ per ml. Adherent cells were obtained by scraping with a rubber policeman and pooled with nonadherent cells, resuspended in PBS, and labeled with $\left[{ }^{3} \mathrm{H}\right] \mathrm{DFP}$ $(\sim 10 \mu \mathrm{M})$ at $37^{\circ} \mathrm{C}$ for $45 \mathrm{~min}$. Labeled cells were pelleted by centrifugation and lysed in sample buffer. The labeled bands were visualized after SDS-PAGE and autoradiography. A similar procedure was followed for labeling PBMCs as well. However, in this case, pooled PBMCs, cultured in 96-well plates, were labeled with $\left[{ }^{3} \mathrm{H}\right]$ DFP directly in the plate.

Assay for adherent cells. Adherence of cells to tissue culture plastic was assessed by direct visual inspection of washed wells, or after staining adherent cells with Giemsa. In some experiments a quantitative estimate of adherence was obtained by using the $\left[{ }^{3} \mathrm{H}\right]$ thymidine protocol described earlier $(18,19)$.

Northern analysis. Whole cell RNA was isolated for analysis of steady state mRNA levels as previously described $(19,37)$. Cells $(6$ $\times 10^{6} /$ well; 6-well plate) were lysed and RNA pelleted in presence of $20 \mu \mathrm{g}$ carrier yeast t-RNA. Purity and concentration of the RNA were determined by $A_{260}$ and $A_{280} \mathrm{~nm}$. After electrophoresis in agarose-formaldehyde gels, RNA was transferred to a nylon filter and fixed by UV cross-linking. Equivalence and quality of RNA transferred was verified by visualization of the $28 \mathrm{~S}$ and $18 \mathrm{~S}$ RNA bands under UV illumination. Filters were sequentially hybridized with appropriate $\alpha\left[{ }^{32} \mathrm{P}\right] \mathrm{dATP}$ labeled probes (Multiprime DNA-labeling system; Amersham Corp., Arlington Heights, IL). The intensity of signals obtained after autoradiography was evaluated using scanning densitometry.

$T N F \alpha$ assay. Cell free supernatants were assayed for TNF $\alpha$ activity by using the L-929 cytolytic assay (38). Briefly, L-929 cells were cultured with test samples in a 96-well plate at $37^{\circ} \mathrm{C}$ for $24 \mathrm{~h}$ in a humidified $\mathrm{CO}_{2}$ incubator in presence of Actinomycin D $(1 \mu \mathrm{g} / \mathrm{ml})$. Lytic activity was assessed by measuring crystal violet uptake at 600 $\mathrm{nm}$ using an ELISA reader. Neutralizing anti-TNF $\alpha$ antibodies were used to ensure that all lytic activity in supernatants was due to TNF $\alpha$.

\section{Results}

In agreement with previous results (4-11), in vitro macrophage differentiation, studied by using human myeloid cells as well as PBMCs, was accompanied by extensive changes in the profile of protease expression. The sections below detail the changes that are dependent upon autocrine UPAR occupancy.

Antibodies to $U P A R$ and $U P A$ inhibit cat $B$ expression during macrophage differentiation. Expression of the $31-\mathrm{kD}$ cat $\mathrm{B}-\mathrm{like}$ protein increased in both stimulated U937 (Fig. 1, compare lanes 2 and 6 with 1 and 5) and cultured PBMCs (Fig. 1, lanes 9 and 10). Western blotting and immunoprecipitation with anticat B IgG confirmed that the $31-\mathrm{kD}$ band was cat B (not shown). The presence of high levels of cat $B$ in alveolar macrophages (Fig. 1, lane 13) confirmed that expression of this protein is a reliable marker of macrophage differentiation. Higher molecular mass proteins, identical to the $\sim 40-\mathrm{kD}$ band seen in Fig. $1 B$, were also observed by active-site labeling of human kidney 293 cells stably transfected with human cat B. Thus, these higher bands are likely to be precursor forms of cat B (Chapman, H. A., unpublished observation). This is consistent with the observation that precursors of the canonical cysteine protease, papain, are also labeled by E-64 analogues (39). The influence of UPAR occupancy on the expression of the major form of active cat $B$ (the $31-\mathrm{kD}$ band) was investigated further.

In agreement with a recent report (35), flow cytometry indicated that a substantial percentage $(\sim 50 \%)$ of the receptors in unstimulated U937 cells were occupied by endogenously produced uPA (not shown). Treatment with PMA for $24 \mathrm{~h}$ increased cell surface uPAR expression several-fold, but as expected the relatively modest increase in uPA expression resulted in the occupancy of only a small percentage of receptors $(\sim 10$ $25 \%$ ). However, adding saturating amounts of uPA or receptorbinding fragments thereof did not alter the expression of either cathepsin B or MMP-9 (not shown). Thus, the effect of abrogating uPAR occupancy on protease expression was investigated.

Initial experiments indicated that polyclonal and $\mathrm{mAbs}$ to UPAR, made to the ligand-binding domain of the receptor, blocked PMA-induced adhesion of myeloid cells in a dosedependent manner. Furthermore, this block in adhesion could be overcome by DFP-uPA at concentrations shown previously to reverse the block in adhesion caused by anti-uPA (18). Based on these observations an optimal concentration of antibodies was chosen to investigate the effect of uPAR occupancy on protease expression. Polyclonal (Fig. 1, lane 3 ) as well as monoclonal (Fig. 1, lanes 7 and 8) antibodies to uPAR inhibited $\mathrm{PMA} / \mathrm{D}_{3}$-induced increase in cat $\mathrm{B}$; nonimmune $\mathrm{IgG}$ was not inhibitory (Fig. 1, lane 4). Furthermore, immunodepletion of uPAR antibodies on s-uPAR-coated plates, as described earlier, 

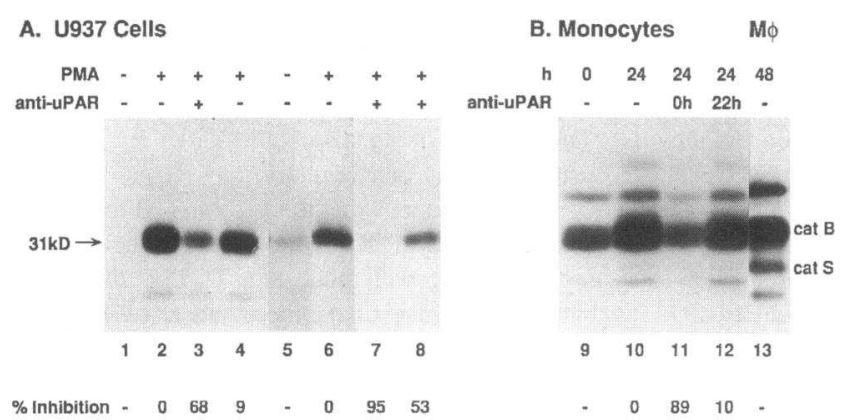

\section{Monocytes}

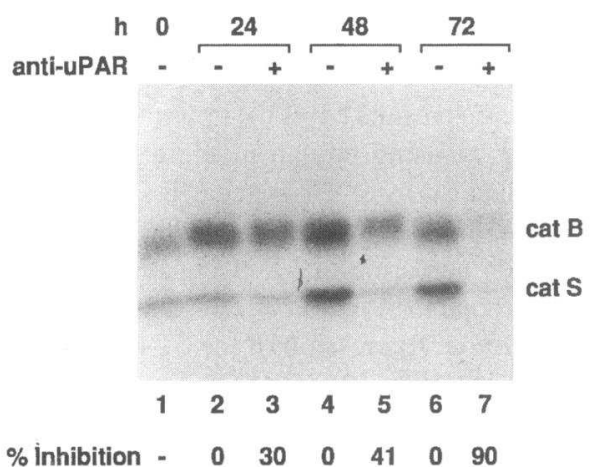

Figure 1. uPAR occupancy influences active cat B expression during macrophage differentiation. $(A)$ Pooled adherent and nonadherent U937 cells were collected and labeled with the active site probe, $\left[{ }^{125} \mathrm{I}\right] \mathrm{Y}-\mathrm{A}-$ $\mathrm{CHN}_{2}$, as described. Lanes 1 and 5 represent unstimulated cells and lanes 2 and 6 represent cells after $24-\mathrm{h} P M A / D_{3}$ stimulation. Stimulation was in the presence of $400 \mu \mathrm{g} / \mathrm{ml}$ polyclonal anti-uPAR IgG (lane 3) or nonimmune IgG (lane 4 ), or $50 \mu \mathrm{g} / \mathrm{ml}$ monoclonal antibodies to uPAR, MA13 (lane 7) or MA113 (lane 8). (B) Pooled adherent and nonadherent PBMC lysates were labeled with the E-64 analogue, [ $\left.{ }^{125} \mathrm{I}\right]-$ JPM, as described. Lanes 9 and 10 represent PBMC lysates obtained before and after $24 \mathrm{~h}$ of culture, respectively. MA13 was added either at the initiation of culture (lane 11) or $\sim 22 \mathrm{~h}$ after start of culture (lane 12). Lane 13 shows the pattern of cysteine protease expression in the fully differentiated alveolar macrophage. As lane 13 was obtained from a $13 \%$ gel and lanes $9-12$ from a $10 \%$ gel, the cat B and cathepsin S-like bands do not comigrate. (C) PBMC lysates obtained before (lane 1) and after 24 (lanes 2 and 3), 48 (lanes 4 and 5), and $72 \mathrm{~h}$ (lanes 6 and 7) of culture were labeled with [ $\left.{ }^{125} \mathrm{I}\right] \mathrm{JPM}$ as described. MA13 $(50 \mu \mathrm{g} / \mathrm{ml})$ when added at the initiation of culture (lanes 3,5 , and 7) inhibited both cat B and cathepsin S-like proteins. Results in $A$ and $B$ are representative of at least three separate experiments and those in $C$ are representative of two separate experiments. The percent inhibition by each of the antibodies, shown under the lanes, was determined by densitometry of the autoradiographs.

removed much $(\sim 60 \%)$ of the inhibitory activity of these antibodies (not shown).

In vitro culturing of PBMCs is accompanied by increases in plasminogen activator activity $(40,41)$, cell surface uPAR (42), as well as increased active cat B expression (Fig. 1, lane 10). Therefore, we studied if a similar dependence for UPAR occupancy could be demonstrated in PBMCs. mAbs to uPAR, added at the start of culture, inhibited the expression of cat $B$ $(75 \pm 11 \%, n=3)$ during a $24 \mathrm{~h}$ culture. Additionally, these antibodies also blocked the up-regulation of the cathepsin Slike protein (36) in cultured PBMCs. However, addition of the antibody $\sim 22 \mathrm{~h}$ after initiation of culture had no inhibitory
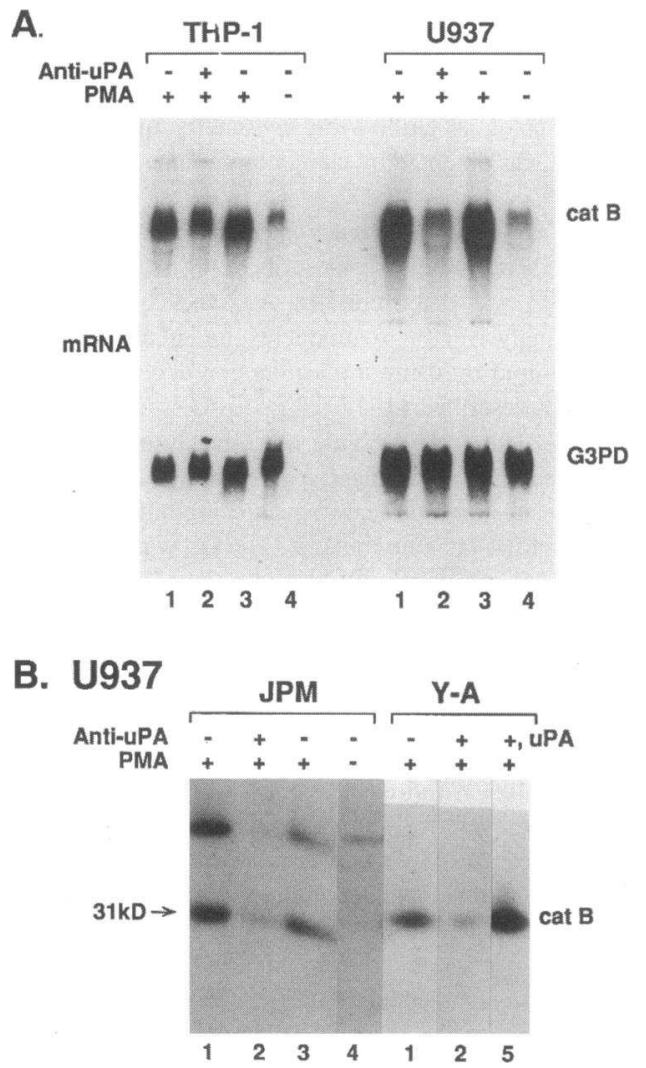

Figure 2. uPAR occupancy influences cat $B$ mRNA expression during macrophage differentiation. $(A)$ Whole cell RNA isolated from myeloid cells was analyzed for expression of cat $B$ and G3PD as described.

PMA-induced differentiation was either in the absence (THP-1) or presence (U937) of vit $\mathrm{D}_{3}$. Stimulus was either in the absence (lane 1 ) or presence of $175 \mu \mathrm{g} / \mathrm{ml}$ anti-uPA (lane 2), of $175 \mu \mathrm{g} / \mathrm{ml} \mathrm{rabbit} \mathrm{nonim-}$ mune serum (lane 3 ); unstimulated cells were used as control (lane 4). $(B)$ The effect of these treatments on cat B protein was assessed by labeling U937 cells obtained from a parallel plate with [ ${ }^{125}$ I]JPM. Also shown by [ $\left.{ }^{125} \mathrm{I}\right] \mathrm{Y}$-A labeling of cells obtained from a separate experiment is that $100 \mathrm{nM}$ DFP-uPA (lane 5) overcomes the inhibitory effect of $125 \mu \mathrm{g} / \mathrm{ml}$ anti-uPA (lane 2). Densitometric analysis indicated that anti-uPA inhibited cat B mRNA by $>50 \%$ and protein by $>80 \%$. Representative results from at least three separate experiments are shown.

effect (Fig. 1, compare lane 11 with lane 12). These antibodies were also effective in inhibiting cat $\mathrm{B}$ expression during 48and 72-h culture of PBMCs (Fig. 1C).

Preliminary experiments showed that PMA-mediated increase of cat B protein in $\mathrm{U} 937$ cells is accompanied by a parallel increase in the steady-state level of cat B mRNA. Timecourse Northern analysis indicated that the increase in cat $B$ mRNA ( $\sim 18 \mathrm{~h}$ after stimulus) temporally followed the increase in uPA mRNA ( $\sim 2-4 \mathrm{~h}$ after stimulus, not shown). Thus, we investigated if abrogating receptor occupancy by using anti-uPA, affects the steady-state levels of cat B mRNA. AntiuPA (but not nonimmune serum) consistently inhibited the PMA/D $/ D_{3}$-induced increase of cat B mRNA (Fig. 2 A). Experiments done in parallel indicated that the pattern of active cat $B$ expression correlated with levels of cat B mRNA (Fig. $2 \mathrm{~B}$, lanes 1-4). Exogenous DFP-uPA reversed the anti-uPA-mediated block (Fig. $2 \mathrm{~B}$, compare lane 2 with lane 5 ), confirming 


\section{B. U937}

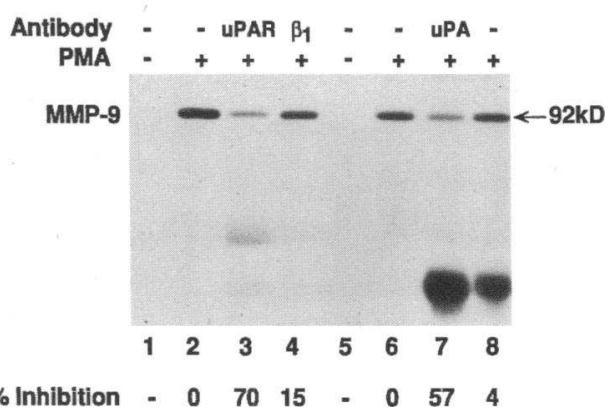

Figure 3. uPAR occupancy influences the expression of MMP-9 in PMA-stimulated myeloid cells. $(A)$ The Northern blot shown in Fig. 2 was stripped and reprobed for MMP-9. Stimulus was either in the absence (lane 1 ) or presence of anti-uPA (lane 2), or nonimmune serum (lane 3). Unstimulated cells are shown in lane 4. An MMP-9 Western blot of THP-1 cell-free supernatants obtained from a separate experiment is shown for comparison. $(B)$ Cell-

free supernatants obtained from U937 cells cultured with 5\% FBS were separated by SDS-PAGE (8\%) and blotted as described. Lanes 1 and 5 represent conditioned media from unstimulated cells. PMA stimulus was either in the absence (lanes 2 and 6 ) or presence of the following antibodies: MA13 (lane 3, $33 \mu \mathrm{g} / \mathrm{ml}$ ), monoclonal anti-CD29 (lane 4, $66 \mu \mathrm{g} / \mathrm{ml}$ ), polyclonal anti-uPA (lane 7, $175 \mu \mathrm{g} / \mathrm{ml}$ ), or rabbit nonimmune serum (lane $8,175 \mu \mathrm{g} / \mathrm{ml}$ ). The anti-rabbit ${ }^{125} \mathrm{I}-\mathrm{IgG}$ secondary antibody also detects rabbit IgG present in the (anti) serum used (the low $M_{\mathrm{r}}$ bands in lanes 7 and 8). Representative results from at least three separate experiments are shown.

the dependence of cat B expression on uPAR occupancy. Similar results were obtained when cat $B$ activity was assessed by using the fluorogenic dipeptide (Z-F-R-NMec) as substrate (not shown). Thus, anti-uPA and anti-uPAR antibodies block cat $B$ expression and do so at the level of mRNA.

Antibodies to $U P A$ and $U P A R$ inhibit MMP-9 expression during macrophage differentiation. Time course analysis of PMA-stimulated leukemic cells shows a time-dependent increase, starting $\sim 12 \mathrm{~h}$ after stimulus, in MMP-9 mRNA and protein (43). Thus, we sought to determine if uPAR occupancy influenced the expression of MMP-9 in U937 and THP-1 cells. In agreement with previous results $(7,11,43)$, the expression of the MMP-9 protein was enhanced several-fold in PMA-stimulated THP-1 cells (Fig. 3 A, lane 1) and U937 cells (Fig. 3 $B$, lanes 2 and 6 ). As observed in the case of cat $B$, antibodies to uPA but not nonimmune serum inhibited phorbol ester-induced up-regulation of MMP-9 mRNA in both U937 (not shown) and THP-1 cells (Fig. 3 A, lanes 2 and 3). Antibodies to the uPA receptor also inhibited the expression of MMP-9 in both THP-1 (not shown) and U937 cells (Fig. $3 \mathrm{~B}$, lane 3 ). Essentially similar results were obtained by using gelatin zymography. The effect of these treatments on the secretion of MMP-9 by PBMCs was not evaluated as the increase in MMP9 expression in these cells during short term in vitro culture is minimal.

Analysis of the mechanism by which UPAR influences cat B and MMP-9 expression. Based on prior observations in other cellular systems that both the catalytic and receptor binding activities of uPA can elicit cellular responses (26-30), we questioned whether the uPA- and uPAR-dependent responses described above also required the catalytic activity of uPA. The addition of anti-catalytic urokinase antibodies at concentrations verified to block all cell surface uPA activity $(10 \mu \mathrm{g} / \mathrm{ml})$ had no effect on cat B or MMP-9 expression by PMA-stimulated U937 cells. The addition of the plasmin inhibitor aprotinin ( 250 $\mathrm{KIU} / \mathrm{ml}$ ) also did not inhibit the expression of cat B or MMP9. Furthermore, the addition of excess (100 nM) DFP-inactivated uPA did not inhibit protease expression. Higher concentrations of this reagent could be expected to displace any active uPA from the cell surface. Together, these observations imply that the catalytic activity of uPA may not be directly involved in regulation of protease expression by these cells. This conclu- sion is supported by results with monoclonal antibodies directed against domains $2 / 3$ of uPAR. Two such antibodies (R4 and $\mathrm{R} 2$ at $50 \mu \mathrm{g} / \mathrm{ml}$ ) were tested (Table I). Although the specific epitopes on domains $2 / 3$ to which these antibodies are directed are unknown, neither antibody influences the uPAR-binding or catalytic activities of uPA (44). One of these antibodies, R4, which has been shown to inhibit vitronectin binding to UPAR (21) also inhibited MMP-9 expression ( 50\%) in PMA-stimulated U937 cells. Thus, anti-vitronectin antibodies were used to assess the role of vitronectin in PMA-induced adhesion and protease expression by U937 cells. Polyclonal anti-vitronectin antibodies were obtained from four different sources (Chemicon, Temecula, CA; GIBCO BRL; Becton Dickinson and Calbiochem Novabiochem, La Jolla, CA) and only those obtained from Calbiochem Novabiochem were observed to block the adhesion of PMA-stimulated U937 cells in a dose-dependent

Table I. Effect of Various Antibodies on PMA-induced Markers of Macrophage Differentiation

\begin{tabular}{lccc}
\hline \multicolumn{1}{c}{ Antibodies } & Adhesion & Cathepsin B & MMP-9 \\
\hline None & + & + & + \\
Anti-uPA (blocks receptor binding) & - & - & - \\
Anti-uPA (anticatalytic), mAb & + & + & + \\
Anti-uPAR (sheep IgG) & - & - & ND \\
Anti-uPAR, mAb & & & \\
MA13 (domain 1) & - & - & - \\
R2 (domains 2/3) & + & + & + \\
R4 (domains 2/3) & + & ND & - \\
Anti-vitronectin & - & + & + \\
Anti-PAI-1 & + & + & + \\
Anti-CD29, mAb & + & + & + \\
Anti-CD14, mAb & + & + & + \\
Anti-CD55, mAb & + & + & + \\
\end{tabular}

The listed antibodies were added to U937 cells at the initiation of a 24 $h$ culture to assess the effect on PMA-induced adhesion, and expression of cathepsin B and MMP-a. + indicates no inhibition and a - indicates a clear inhibitory ( $>50 \%$ ) effect; ND, not determined. 


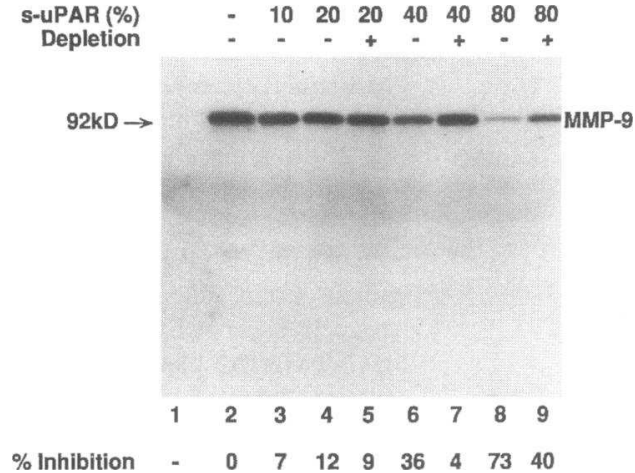

Figure 4. Exogenous soluble uPAR inhibits PMA-induced MMP-9 secretion. MMP-9 Western blotting was performed as described. Lane 1 shows conditioned medium from unstimulated U937 cells. Stimulus was either in the absence (lane 2) or presence of increasing amounts of medium containing s-uPAR at the concentrations indicated in the figure. Depleting the medium of s-uPAR as described ablated the inhibition. The blot was scanned as described and a quantitative estimate of the inhibitory effect of s-uPAR on MMP-9 expression is shown under each lane. Representative results from two separate experiments are shown. Western blot analysis using purified s-uPAR as standard indicated that the concentration of s-uPAR in the conditioned medium was $\sim 12 \mathrm{nM}$. The inhibitory effect of soluble uPAR was also observed by gelatin zymography of additional experiments.

manner. However, antibodies at concentrations which block adhesion had no effect on protease expression.

The specificity of antibodies directed against uPAR for inhibition of protease expression was tested by comparison with a variety of antibodies against other membrane or secreted proteins (Table I). Antibodies to the integrins (CD11a, CD29), the GPI-anchored proteins (CD14, CD55), and secreted proteins (PAI-1), did not inhibit the expression of cat B and MMP-9.

To further assess the importance of uPAR occupancy on protease expression stimulated cells were exposed to a soluble form of uPAR. Soluble forms of cell surface receptors, including s-uPAR, can scavenge the endogenous ligands and thus inhibit occupancy of the cell surface form of the receptor (45). As shown in Fig. 4 there is a dose-dependent inhibition in MMP-9 production (lanes 3, 4, 6, and 8). Moreover, depleting the s-uPAR-containing medium on pro-uPA-coated plates largely ablated the inhibitory affect (lanes 5,7 , and 9 ). Conditioned medium (especially at lower concentrations) obtained from cells transfected with an irrelevant protein, or medium from nontransfected cells did not have an inhibitory affect. Similarly, whereas s-uPAR was able to inhibit cat B in PMA-stimulated U937 cells, depleted s-uPAR was less so (not shown).

Cell surface form of UPAR is critical for protease expression. If the effects being studied are dependent on the cellsurface, GPI-anchored form of uPAR, releasing the anchor should result in a pronounced inhibition of the UPAR-dependent markers. Treatment of MDCK cells for a few hours with MA under glucose-free conditions converts GPI-anchored proteins to secretory products (46). Significantly, treatment of stably transfected 293 cells expressing the GPI-anchored UPAR with $10 \mathrm{mM}$ MA results in the partitioning of the protein into the aqueous phase (21). However, as gene expression is an energy requiring process, initial experiments were directed at determining optimal MA doses under normal, glucose containing ( $2 \mathrm{~g} /$ $\mathrm{ml}$ ) culture conditions. Addition of MA at the start of culture inhibited, in a dose-dependent manner, the adhesion of $24 \mathrm{~h}$ PMA-stimulated myeloid cells to plastic. The concentration of MA that was able to optimally block adhesion without affecting cell viability was determined to be $10 \mathrm{mM}$ (not shown). As shown in Fig. 5 A, $10 \mathrm{mM}$ MA was a potent inhibitor of both cat B and MMP-9 expression in PMA-stimulated U937 cells. Similar results were obtained with the THP-1 cells as well (not shown). The possibility that the MA affect was an artifact of a net decrease in glucose uptake was eliminated by demonstrating that reducing glucose, in absence of MA, did not affect MMP-9 expression (not shown). Temperature-induced phase separation of membrane pellets in Triton X-114 indicated that MA treatment converts the GPI-anchored uPAR, normally seen largely in the detergent phase, into the soluble, aqueous phase (Fig. $5 B$ ).

The $U P A$-dependent processes of adhesion and gene expression can be uncoupled. Adherence plays a pivotal role during the development of precursor cells into macrophages $(22,23)$ and acquisition of an adhesive phenotype is promoted by uPA that activates a high affinity vitronectin binding site on UPAR (19-21). Therefore, we studied if attainment of adhesion itself is critical for cat B and MMP-9 up-regulation. Equal levels of active cat $B$ were induced in $24 \mathrm{~h}$ PMA/ $\mathrm{D}_{3}$-stimulated (compared to unstimulated) cells cultured either on adhesive plastic surfaces or on nonadhesive Teflon surfaces (9.8- and 8.7-foldincrease over unstimulated cells, respectively, $n=3)$. Similarly, no inhibition in cat B expression could be seen in PBMCs cultured on Teflon surfaces. Also, expression of MMP-9 was not impaired when PMA-stimulated U937 cells were cultured on Teflon (not shown). This divergence between the uPAdependent processes of adhesion and gene expression was explored further. As illustrated in Fig. 6, adhesion of PMA/D ${ }^{-}$ stimulated U937 to plastic could be blocked by anti-uPA antibodies, whatever the time of addition. However, anti-uPA blocked cat $B$ expression only when added during the first few hours after stimulus.

Antibodies to UPA and UPAR do not ablate the decrease in cathepsin $G$ expression. ${ }^{3} \mathrm{H}-\mathrm{DFP}$ labeling of U937 and PBMC lysates indicated that the expression of a number of serine enzymes was altered during macrophage differentiation. As has been reported ( 7 ), the expression of the $26-\mathrm{kD}$ cat G-like serine protease as well neutrophil elastase was greatly decreased during differentiation of both myeloid cells and PBMCs. However, PMA-mediated decrease in Cat G protein and mRNA was not affected by anti-uPA (not shown). Similarly, antibodies to uPA and uPAR did not affect the decrease in cat $G$ protein in cultured PBMCs.

$T N F \alpha$ expression is not dependent on UPAR occupancy. Finally, we investigated whether UPAR occupancy influenced the expression of additional PMA-responsive genes. One such gene product is TNF $\alpha$, a potent modulator of macrophage differentiation/activation. More specifically, TNF $\alpha$ enhances adhesion (3) and MMP-9 production in U937 cells (11). Thus, it was possible that the uPA-dependent effects under study were being indirectly modulated by the changes in TNF $\alpha$ levels. In agreement with previous reports $(38,47)$, we observed a several-fold induction of TNF $\alpha$ in $24 \mathrm{~h}$ PMA/D $\mathrm{D}_{3}$-stimulated U937 cells. However, in contrast to adhesion and protease expression, anti-uPA did not affect the induction of TNF $\alpha$ (Fig. 7). Similarly, induction of TNF $\alpha$ by lipopolysaccharide-stimulated 

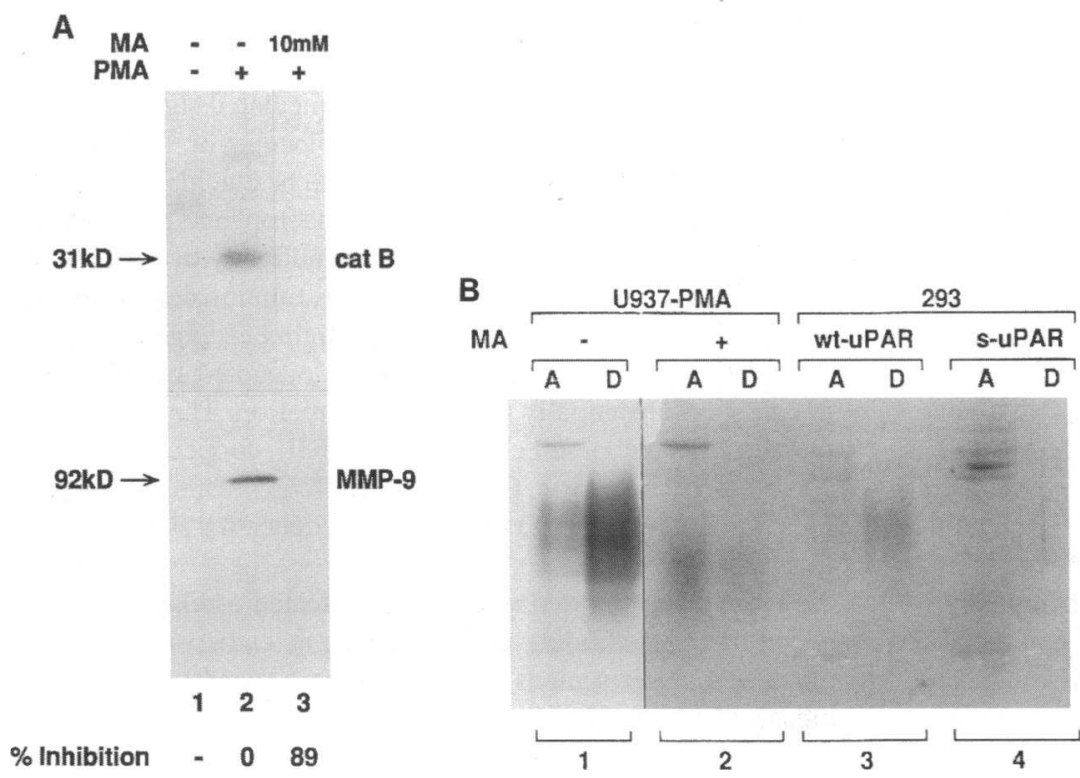

Figure 5. Mannosamine impairs GPI-anchor synthesis and blocks cell surface uPAR-mediated effects. (A) U937 cell lysates were assessed for cat B by using JPM and cell-free supernatants were assessed for MMP-9 by Western blotting. Lane 1 represents unstimulated samples. PMA stimulus was either in the absence (lane 2) or presence of $10 \mathrm{mM}$ MA (lane 3). Similar results were seen in at least three separate experiments. $(B)$ Treatment with MA causes uPAR to partition into the aqueous phase. Temperature-induced phase separation of Triton X114 extracted U937 membranes and Western blotting using polyclonal rabbit anti-uPAR were carried out as described. $A$ and $D$ represent aqueous and detergent phases, respectively. Stimulus was either in absence (lane 1 ) or presence of $10 \mathrm{mM}$ MA (lane 2). 293 kidney epithelial cells transfected with either the construct coding for the full-length, GPI-anchored UPAR (lane 3 ) or for the truncated, soluble form (lane 4) are shown for comparison.

PBMCs was not impaired by antibodies to uPA or uPAR (not shown).

\section{Discussion}

These results indicate that the expression and function of uPAR is important to the pattern of protease expression by differentiating phagocytes. Such a relationship is not readily apparent because the autocrine occupancy of a relatively small percentage of UPAR in PMA-stimulated myeloid cells or PBMCs maximally stimulated the expression of proteases in these cells. That occupancy by an agonist of a very small proportion of receptors can induce a maximal biological response has been demonstrated previously $(48-50)$. Thus, the linkage between uPAR

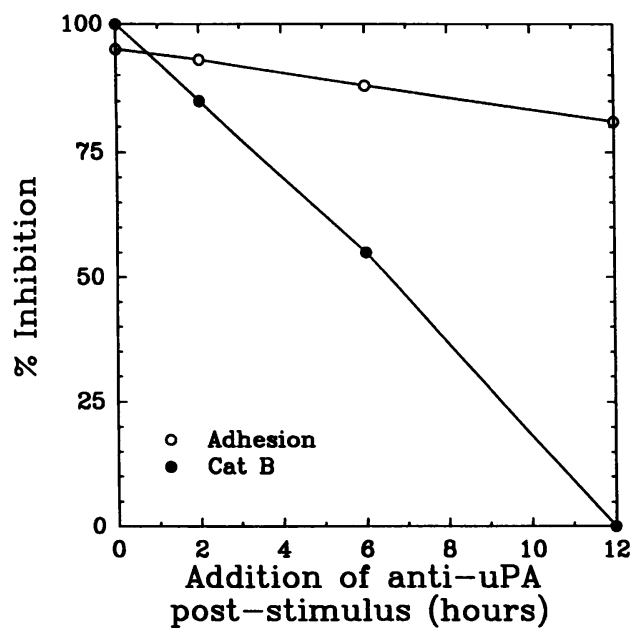

Figure 6. Time course of adhesion and cat B inhibition by anti-uPA. Anti-uPA ( $125 \mu \mathrm{g} / \mathrm{ml}$ ) was added to PMA/vit $\mathrm{D}_{3}$-stimulated U937 cells at different times after stimulus, and the effect on adherence (using $\left[{ }^{3} \mathrm{H}\right]$ thymidine-labeled cells) and on cat B (using JPM-labeled lysates) was assessed as described. Similar results were seen in two separate experiments. occupancy and protease expression was made discernable only by experiments aimed at disrupting endogenous uPA/uPAR interactions. Four independent approaches were used to achieve this: $(a)$ polyclonal and monoclonal antibodies to uPAR directed to the ligand-binding domain of the molecule; $(b)$ polyclonal antibodies to uPA which have been shown to prevent receptor occupancy (18); (c) conditioned medium from transfected 293 cells expressing soluble uPAR that should compete with the cell surface receptor for endogenous UPA; and finally $(d)$ by using MA, a reagent shown to impair GPI anchor synthesis and hence inhibit cell surface expression of GPI-anchored proteins including UPAR. All four lines of experiments yielded results supporting the conclusion that anchored-uPAR influences cellular signaling and modulates protease gene expression in phagocytes. These data establish that uPA, analo-

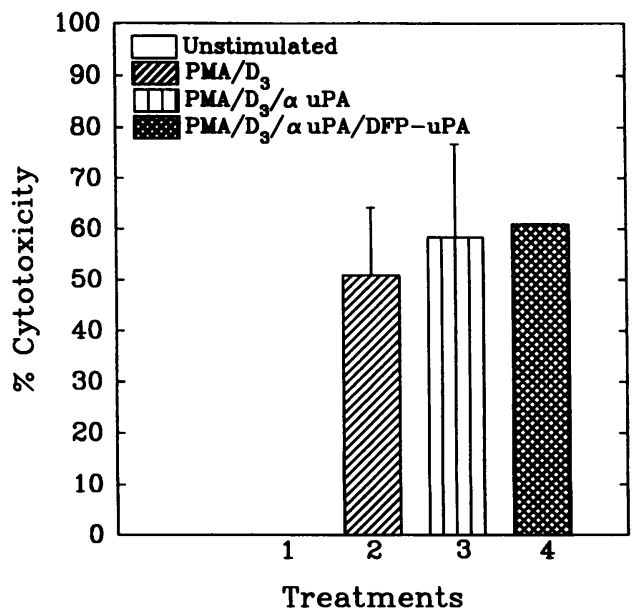

Figure 7. Expression of TNF $\alpha$ by U937 cells is not affected by uPAR occupancy. Cell-free supernatants were assessed for TNF $\alpha$ activity by using the L-929 cytotoxicity assay as described. Anti-uPA ( $125 \mu \mathrm{g} / \mathrm{ml})$ in absence or presence of DFP-uPA ( $100 \mathrm{nM})$ did not inhibit PMA/ $\mathrm{D}_{3}$-mediated increase in TNF $\alpha$ activity. Bars indicate mean $\pm \mathrm{SD}, n=3$; absence of bars indicates mean from two separate experiments. 
gous to thrombin $(51,52)$, confers multiple functional properties on cells expressing its receptor.

Though the exact mechanism by which uPAR regulates protease expression in differentiating phagocytes is unclear, our data provide evidence germane to this point. Whereas it is possible that the catalytic activity of uPA is integral to signaling via uPAR, multiple lines of evidence argue against this possibility. Neither anticatalytic antibodies against uPA, displacement from uPAR of endogenous (potentially activated) uPA by excess inactive enzyme, nor inhibitors of plasmin inhibited protease expression in our assays. Rather, only reagents that either blocked occupancy of uPAR by uPA (anti-uPA, anti-uPAR, and s-uPAR) or blocked cell surface receptor expression itself (MA) interfered with protease expression. This is consistent with prior reports that UPA can transduce cellular signals independent of its catalytic activity (28-30). As adherence plays a pivotal role in the maturation and activation of macrophages $(22,23,53)$, a distinct possibility was that UPAR occupancy was influencing gene expression by modulating macrophage adhesion. Our data argue against this. Firstly, neither the expression of cat B nor of MMP-9 was affected by culturing cells on nonadhesive Teflon surfaces. Secondly, regardless of the time of addition, anti-uPA blocked the adhesion of PMA-stimulated cells to plastic. However, cat B was inhibited only when antiuPA was added within a few hours of start of culture (Fig. 6 ). This suggests that whereas continued uPAR occupancy is required for adhesion, early occupancy may facilitate a second set of signals, induced by the stimulus, to enhance cathepsin expression. Finally, antibodies to both UPA and UPAR inhibited cat B expression but not adhesion of PBMCs. All this suggests that the two processes, adhesion and gene expression, are differentially influenced by uPAR. Another possible mechanism for signaling may involve interactions of uPA-bound UPAR with the $\alpha_{2}$-macroglobulin receptor/LDL receptor-related protein (LRP) (54). However, the observation that the 39-kD LRPrelated protein (RAP), which blocks all such interactions, did not inhibit protease expression in PMA-stimulated cells (Rao, N., unpublished observation) makes it unlikely that the uPARmediated signaling under study operates via this pathway.

These findings raise the possibility that the recently identified novel function of UPAR as a high affinity receptor for vitronectin (21) underlies its potential to regulate protease gene expression in phagocytes. Our data argue against this possibility as antibodies to vitronectin influenced neither cat B nor MMP-9 expression in our assays. Yet, R4, one of the antibodies directed against domains $2 / 3$ of uPAR, and known to inhibit vitronectin binding (21), also inhibited MMP-9 expression. Thus it seems likely that domains $2 / 3$ of uPAR associates, in a uPA-dependent manner, with a distinct membrane adaptor molecule, and influences the gene expression reported here. Recent reports have indicated that several GPI-anchored receptors associate with adaptor molecules, such as gp $130(25,55)$, which in combination with nontransmembrane tyrosine kinases induce liganddependent cellular responses $(24,56)$. An alternative mechanism for signaling via uPAR may involve caveolin, a $22-\mathrm{kD}$ transmembrane protein that is an invariant component of membrane invaginations called caveolae $(57,58)$. Interestingly, Western blots using specific mAbs to caveolin indicated that this $22-\mathrm{kD}$ protein is expressed in PMA-stimulated myeloid cells (Rao, N., unpublished observation). Oligomerization of GPI-anchored proteins results in their selective enrichement together with an array of signaling molecules inside caveolae
$(59,60)$. The physiological mechanism by which such proteins oligomerize and sequester in caveolae is not known. However, we have no direct evidence that UPAR-mediated signaling operates either via gp 130-like adaptor molecules or via caveolin, and the molecular mechanisms remain to be elucidated. Further, whether UPAR occupancy influences macrophage gene expression by directly transducing signals or indirectly by cooperating with other receptor systems to facilitate stimulus-dependent signaling is unclear. A cooperative role might be suggested by our observation that the fraction of UPAR occupied by UPA does not change substantially during differentiation. The observation that the GPI-anchored Fc receptor, Fc $\gamma$ RIII, cooperates with the complement receptor 3, CR3 (Mac-1), to generate a respiratory burst in neutrophils (61) provides precedence for such cooperativity.

Previously reported work has implicated a relationship between matrix-degrading proteases such as cathepsins B and $S$, metalloproteases such as $92-\mathrm{kD}$ gelatinase (MMP-9), and urokinase $(17,36,62-65)$. At a functional level these distinct enzyme systems cooperate in extracellular matrix breakdown and in the cross-activation of their precursor forms. However, whether these interactions, which have been demonstrated in vitro, have any physiological relevance is unknown. Our observations, indicating cooperation among these distinct classes of proteins at the level of their own expression, supports a physiological role for these previously observed functional interactions (66-68).

Significantly, not all PMA-induced responses are dependent on uPAR occupancy. Thus, anti-uPA did not affect the induction of either TNF $\alpha$ (Fig. 7) or CD18 (18). Interestingly, TNF $\alpha$ potentiates MMP-9 expression in both unstimulated and PMAstimulated U937 cells (11). Thus, our data raise the possibility that TNF $\alpha$-mediated increase in MMP-9 production may also be influenced by concurrent uPAR occupancy.

Accumulating evidence indicates that the urokinase receptor is a multifunctional protein. Based on the data reported here and previous work by this and other laboratories, three distinct but interacting functions of UPAR can be advanced: $(a)$ the receptor binds and concentrates urokinase at the cell surface where pericellular proteolysis may directly contribute to tissue remodelling and indirectly promote this process by activation of proenzymes and growth factors; $(b)$ the receptor acts as a vitronectin receptor and promotes high affinity attachment of cells to the matrix-like form of vitronectin (21). This function intrinsically links matrix attachment with regulation of cell surface uPA activity. This function may also contribute to the signaling properties of this receptor as cell-matrix interactions are known to alter cell shape and clustering of integrin receptors can mediate signals affecting the differentiation and function of many cell types (69). However, our data are not easily explained by events secondary to adhesion, for the reasons stated above; (3) the receptor appears to either directly or cooperatively transduce signals and influence cellular differentiation/ activation by yet to be elucidated mechanisms. Indeed, uPAR occupancy, per se, independent of catalytic activity stimulates human osteosarcoma cell mitogenesis (28), epidermal cell chemotaxis (29), epithelial cell migration (30), and bovine endothelial cell motility (70). Furthermore, uPAR has been demonstrated to facilitate monocyte chemotaxis independent of uPA (71) and transfection of human kidney 293 cells with the GPIanchored form of uPAR, but not the soluble form of the protein, results in uPA-independent neosynthesis of a gelatin-degrading 
protease in these transfected cells (Rao, N., unpublished observation). Taken together these observations establish the multifunctional nature of cell surface uPAR. It is therefore tempting to speculate that deficiency in the expression of uPAR in patients suffering from paroxysmal nocturnal hemoglobinuria (72) may contribute not only to venous thrombosis but also to some of the other problems such as susceptibility to infection, increased incidence of leukemia, and a general disorder of hematopoiesis (73), which characterize this disease.

\section{Acknowledgments}

We thank Drs. J. Munger, Y. Wei, R. Todd, W. Knapp, E. Ronne, J. Henkin, S. Shapiro, C. Parker, R. Mason, A. Nykjaer, and T. Pourmotabbed for their generous gifts of reagents, Dr. E. Ingenito for his assistance with TNF $\alpha$ cytotoxicity assays, Drs. D. Simon and Hui Xu for their assistance with gelatin zymography, and L. Sailor for technical assistance.

This work was supported by the National Health Service Grant 48261 and a National Institutes of Health predoctoral training grant.

\section{References}

1. Rovera, G., D. Santoli, and C. Damsky. 1979. Human promyelocytic leukemia cells in culture differentiate into macrophage-like cells when treated with a phorbol diester. Proc. Natl. Acad. Sci. USA. 76:2779-2783.

2. Sundstrom, C., and K. Nilsson. 1976. Establishment and characterization of a human histiocytic lymphoma cell line (U937). Int. J. Cancer. 17:565-577.

3. Hass, R. 1992. Retrodifferentiation - an alternative biological pathway in human leukemia cells. Eur. J. Cell Biol. 58:1-11.

4. Welgus, H. G., N. L. Connolly, and R. M. Senior. 1986. 12-o-Tetradecanoylphorbol-13-acetate-differentiated U937 cells express a macrophage-like profile of neutral proteinases: high levels of secreted collagenase and collagenase inhibitor accompany low levels of intracellular elastase and cathepsin G. J. Clin. Invest. 77:1675-1681.

5. Gross, T. J., and R. G. Sitrin. 1990. The THP-1 cell line is a urokinasesecreting mononuclear phagocyte with a novel defect in the production of plasminogen activator inhibitor-2. J. Immunol. 144:1873-1879.

6. Burnett, D., J. Crocker, and A. T. M. Vaughan. 1983. Synthesis of cathepsin B by cells derived from the HL60 promyelocytic leukaemia cell line. J. Cell. Physiol. 115:249-254.

7. Welgus, H. G., E. J. Campbell, J. D. Cury, A. Z. Eisen, R. M. Senior, S. M. Wilhelm, and G. I. Goldberg. 1990. Neutral metalloproteinases produced by human mononuclear phagocytes-enzyme profile, regulation, and expression during cellular development. J. Clin. Invest. 86:1496-1502.

8. Stein, M., T. Braulke, K. V. Figura, and A. Hasilik. 1987. Effects of differentiation-inducing agents on synthesis, maturation and secretion of cathepsin D in U937 and HL-60 cells. Biol. Chem. Hoppe-Seyler. 368:413-418.

9. Campbell, E. J., J. D. Cury, S. D. Shapiro, G. I. Goldberg, and H. G. Welgus. 1991. Neutral proteinases of human mononuclear phagocytes - cellular differentiation markedly alters cell phenotype for serine proteinases, metalloproteinases, and tissue inhibitor of metalloproteinases. J. Immunol. 146:1286-1293.

10. Hanson, R. D., N. L. Connolly, D. Burnett, E. J. Campbell, R. M. Senior, and T. J. Ley. 1990. Developmental regulation of the human cathepsin G gene in myelomonocytic cells. J. Biol. Chem. 265:1524-1530.

11. Watanabe, H., I. Nakanishi, K. Yamashita, T. Hayakawa, and Y. Okada 1993. Matrix metalloproteinase-9 ( $92 \mathrm{kDa}$ gelatinase/type IV collagenase) from U937 monoblastoid cells: correlation with cellular invasion. J. Cell. Sci. 104:991999.

12. Stoppelli, M. P., A. Corti, A. Soffientini, G. Cassani, F. Blasi, and R. K. Assoian. 1985. Differentiation-enhanced binding of the amino-terminal fragment of human urokinase plasminogen activator to a specific receptor on U937 monocytes. Proc. Natl. Acad. Sci. USA. 82:4939-4943.

13. Picone, R., E. L. Kajtaniak, L. S. Nielsen, N. Behrendt, M. R. Mastronicola, M. V. Cubellis, M. P. Stoppelli, S. Pedersen, K. Dano, and F. Blasi. 1989. Regulation of urokinase receptors in monocyte-like U937 cells by phorbol ester, phorbol myristate acetate. J. Cell Biol. 108:693-702.

14. Lund, L. R., E. Ronne, A. L. Roldan, N. Behrendt, J. Romer, F. Blasi, and K. Dano. 1991. Urokinase receptor mRNA level and gene transcription are strongly and rapidly increased by phorbol myristate acetate in human monocytelike U937 cells. J. Biol. Chem. 266:5177-5181.

15. Plow, E. F., D. E. Freaney, J. Plescia, and L. A. Miles. 1986. The plasminogen system and cell surfaces: evidence for plasminogen and urokinase receptors on the same cell type. J. Cell Biol. 103:2411-2420.
16. Ellis, V., M. F. Scully, and V. V. Kakkar. 1989. Plasminogen activation initiated by single chain urokinase-type plasminogen activator: potentiation by U937 cells. J. Biol. Chem. 264:2185-2188.

17. Alexander, C. M., and Z. Werb. 1989. Proteinases and extracellular matrix remodeling. Curr. Opin. Cell Biol. 1:974-982.

18. Nusrat, A. R., and H. A. Chapman. 1991. An autocrine role for urokinase in phorbol ester-mediated differentiation of myeloid cell lines. J. Clin. Invest. 87:1091-1097.

19. Waltz, D. A., L. Z. Sailor, and H. A. Chapman. 1993. Cytokines induce urokinase-dependent adhesion of human myeloid cells: A regulatory role for plasminogen activator inhibitors. J. Clin. Invest. 91:1541-1552.

20. Waltz, D. A., and H. A. Chapman. 1994. Reversible cellular adhesion to vitronectin linked to urokinase receptor occupancy. J. Biol. Chem. 269:1474614750.

21. Wei, Y., D. A. Waltz, N. Rao, R. J. Drummond, S. Rosenberg, and H. A. Chapman. 1994. Identification of the urokinase receptor as an adhesion receptor for vitronectin. J. Biol. Chem. 269:32380-32388.

22. Haskill, S., C. Johnson, D. Eierman, S. Becker, and K. Warren. 1988. Adherence induces selective mRNA expression of monocyte mediators and protooncogenes. J. Immunol. 140:1690-1694.

23. Eierman, D. F., C. E. Johnson, and J. S. Haskill. 1989. Human monocyte inflammatory mediator gene expression is selectively regulated by adherence substrates. J. Immunol. 142:1970-1976.

24. Stefanova, I., V. Horejsi, I. J. Ansotegui, W. Knapp, and H. Stockinger. 1991. GPI-Anchored cell-surface molecules complexed to protein tyrosine kinases. Science (Wash. DC). 254:1016-1019.

25. Ip, N. Y., S. H. Nye, T. G. Boulton, S. Davis, T. Taga, Y. Li, S. J. Birren, K. Yasukawa, T. Kishimoto, D. J. Anderson, N. Stahl, and G. D. Yancopoulos. 1992. CNTF and LIF act on neuronal cells via shared signaling pathways that involve the IL-6 signal transducing receptor component gp130. Cell. 69:11211132.

26. He, C.-J., J.-M. Rebibou, M.-N. Peraldi, Q. Meulders, and E. Rondeau. 1991. Growth factor-like effect of urokinase type plasminogen activator in human renal cells. Biochem. Biophys. Res. Commun. 176:1408-1416.

27. Kirchheimer, J. C., G. Christ, and B. R. Binder. 1989. Growth stimulation of human epidermal cell by urokinase is restricted to the intact active enzyme. Eur. J. Biochem. 181:103-107.

28. Rabbani, S. A., A. P. Mazar, S. M. Bernier, M. Haq, I. Bolivar, J. Henkin, and D. Goltzman. 1992. Structural requirements for the growth factor activity of the amino-terminal domain of urokinase. J. Biol. Chem. 267:14151-14156.

29. Del Rosso, M., E. Anichini, N. Pedersen, F. Blasi, G. Fibbi, M. Pucci, and M. Ruggiero. 1993. Urokinase-urokinase receptor interaction: non-mitogenic signal transduction in human epidermal cells. Biochem. Biophys. Res. Commun. 190:347-352.

30. Busso, N., S. K. Masur, D. Lazega, S. Waxman, and L. Ossowski. 1994. Induction of cell migration by pro-urokinase binding to its receptor: possible mechanism for signal transduction in human epithelial cells. J. Cell Biol. 126:259-270.

31. Ways, D. K., R. C. Dodd, T. E. Bennett, T. K. Gray, and H. S. Earp. 1987. 1,25-Dihydroxyvitamin D3 enhances phorbol ester-stimulated differentiation and protein kinase C-dependent substrate phosphorylation activity in U937 human monoblastoid cell. Endocrinology. 121:1654-1661.

32. Bordier, C. 1981. Phase separation of integral membrane proteins in Triton X-114 solution. J. Biol. Chem. 256:1604-1607.

33. Estreicher, A., A. Wohlwend, D. Belin, W.-D. Schleuning, and J.-D. Vassalli. 1989. Characterization of the cellular binding site for the urokinase-type plasminogen activator. J. Biol. Chem. 264:1180-1189.

34. Chapman, H. A., P. Bertozzi, L. Z. Sailor, and A. R. Nusrat. 1990. Alveolar macrophage urokinase receptors localize enzyme activity to the cell surface. Am. J. Physiol. 259:L432-L438.

35. Sitrin, R. G., R. F. Todd, I. F. Mizukami, T. J. Gross, S. B. Shollenberger, and M. R. Gyetko. 1994. Cytokine-specific regulation of urokinase receptor (CD87) expression by U937 mononuclear phagocytes. Blood. 84:1268-1275.

36. Shi, G.-P., J. S. Munger, J. P. Meara, D. H. Rich, and H. A. Chapman. 1992. Molecular cloning and expression of human alveolar macrophage cathepsin S, an elastinolytic cysteine protease. J. Biol. Chem. 267:7258-7262.

37. Chirgwin, J. M., A. E. Przybyla, R. J. MacDonald, and W. J. Rutter 1979. Isolation of biologically active ribonucleic acid from sources enriched in ribonuclease. Biochemistry. 18:5294-5299.

38. Nedwin, G. E., L. P. Svedersky, T. S. Bringman, M. A. Palladino, and D. V. Goeddel. 1985. Effect of interleukin-2, interferon-gamma and mitogens on the production of tumor necrosis factor alpha and beta. J. Immunol. 135:24922497.

39. Vernet, T., H. E. Khouri, P. Laflamme, D. C. Tessier, R. Musil, B. J. Gour-Salin, A. C. Storer, and D. Y. Thomas. 1991. Processing of the papain precursor-purification of the zymogen and characterization of its mechanism of processing. J. Biol. Chem. 266:21451-21457.

40. Saksela, O., T. Hovi, and A. Vaheri. 1985. Urokinase-type plasminogen activator and its inhibitor secreted by cultured human monocyte-macrophages. $J$. Cell. Physiol. 122:125-132. 
41. Kelley, J. L., M. M. Rozek, C. A. Suenram, and C. J. Schwartz. 1987. Activation of human blood monocytes by adherence to tissue culture plastic surfaces. Exp. Mol. Pathol. 46:266-278.

42. Nykjaer, A., C. M. Petersen, E. I. Christensen, O. Davidsen, and J. Gliemann. 1990. Urokinase receptors in human monocytes. Biochim. Biophys. Acta. 1052:399-407.

43. Saarialho-Kere, U. K., H. G. Welgus, and W. C. Parks. 1993. Distinct mechanisms regulate interstitial collagenase and $92-\mathrm{kDa}$ gelatinase expression in human monocytic-like cells exposed to bacterial endotoxin. J. Biol. Chem. 268:17354-17361.

44. Ronne, E., N. Behrendt, V. Ellis, M. Ploug, K. Dano, and G. HoyerHansen. 1991. Cell-induced potentiation of the plasminogen activation system is abolished by a monoclonal antibody that recognizes the $\mathrm{NH}_{2}$-terminal domain of the urokinase receptor. FEBS (Fed. Eur. Biochem. Soc.) Lett. 288:233-236.

45. Wilhelm, O., U. Weidle, S. Hohl, P. Rettenberger, M. Schmitt, and H. Graeff. 1994. Recombinant soluble urokinase receptor as a scavenger for urokinase-type plasminogen activator (UPA) - inhibition of proliferation and invasion of human ovarian cancer cells. FEBS (Fed. Eur. Biochem. Soc.) Lett. 337:131 134.

46. Lisanti, M. P., M. C. Field, I. W. Caras, A. K. Menon, and E. RodriguezBoulan. 1991. Mannosamine, a novel inhibitor of glycosylphosphatidylinosito incorporation into proteins. EMBO (Eur. Mol. Biol. Orgn.) J. 10:1969-1977.

47. Sung, S.-S. J., J. A. Walters, J. Hudson, and J. M. Gimble. 1991. Tumor necrosis factor-alpha mRNA accumulation in human myelomonocytic cell linesrole of transcriptional regulation by DNA sequence motifs and mRNA stabilization. J. Immunol. 147:2047-2054.

48. Stephenson, R. P. 1956. A modification of receptor theory. Br. J. Pharm 11:379-393.

49. Hohmann, H.-P., R. Remy, B. Poschl, and A. P. G. M. v. Loon. 1990. Tumor necrosis factors $\alpha$ and $\beta$ bind to the same two types of tumor necrosis factor receptors and maximally activate the transcription factor NF- $\kappa$ B at low receptor occupancy and within minutes after receptor binding. J. Biol. Chem. 265:15183-15188.

50. Wiley, H. S., B. J. Walsh, and K. A. Lund. 1989. Global modulation of the epidermal growth factor receptor is triggered by occupancy of only a few receptors. Evidence for a binary regulatory system in normal human fibroblasts. J. Biol. Chem. 264:18912-18920.

51. Shuman, M. A. 1986. Thrombin-cellular interactions. Ann. N.Y. Acad. Sci. 485:228-239.

52. Coughlin, S. R., T. K. Vu, D. T. Hung, and V. I. Wheaton. 1992. Characterization of a functional thrombin receptor. Issues and opportunities. J. Clin. Invest. 89:351-355.

53. Haskill, S., A. A. Beg, S. M. Tompkins, J. S. Morris, A. D. Yurochko, A. Sampson-Johannes, K. Mondal, P. Ralph, and A. S. Baldwin. 1991. Characterization of an immediate-early gene induced in adherent monocytes that encodes I kappa B-like activity. Cell. 65:1281-1289.

54. Nykjaer, A., C. M. Petersen, B. Moller, P. H. Jensen, S. K. Moestrup T. L. Holtet, M. Etzerodt, H. C. Thogersen, M. Munch, P. A. Andreasen, and J. Gliemann. 1992. Purified alpha 2-macroglobulin receptor/LDL receptor-related protein binds urokinase plasminogen activator inhibitor type-1 complex. Evidence that the alpha 2-macroglobulin receptor mediates cellular degradation of urokinase receptor-bound complexes. J. Biol. Chem. 267:14543-14546.

55. Gearing, D. P., C. J. Thut, T. VandenBos, S. D. Gimpel, P. B. Delaney, J. King, V. Price, D. Cosman, and M. P. Beckmann. 1991. Leukemia inhibitory factor receptor is structurally related to the IL-6 signal transducer, gp 130. EMBO (Eur. Mol. Biol. Orgn.) J. 10:2839-2848.

56. Lutticken, C., U. M. Wegenka, J. Yuan, J. Buschmann, C. Schindler, A. Ziemiecki, A. G. Harpur, A. F. Wilks, K. Yasukawa, T. Taga et al. 1994. Association of transcription factor APRF and protein kinase Jak1 with the interleukin-6 signal transducer gp130. Science (Wash. DC). 263:89-92.

57. Glenney, J. R. 1989. Tyrosine phosphorylation of a $22-\mathrm{kDa}$ protein is correlated with transformation by Rous sarcoma virus. J. Biol. Chem. 264:2016320166.

58. Glenney, J. R., and D. Soppet. 1992. Sequence and expression of caveolin, a protein component of caveolae plasma membrane domains phosphorylated on tyrosine in Rous sarcoma virus-transformed fibroblasts. Proc. Natl. Acad. Sci. USA. 89:10517-10521.

59. Sargiacomo, M., M. Sudol, Z. Tang, and M. P. Lisanti. 1993. Signal transducing molecules and glycosyl-phosphatidylinositol-linked proteins form caveolin-rich insoluble complex in MDCK cells. J. Cell Biol. 122:789-807.

60. Mayor, S., K. G. Rothberg, and F. R. Maxfield. 1994. Sequestration of GPI-anchored proteins in caveolae triggered by cross-linking. Science (Wash. DC). 264:1948-1951.

61. Zhou, M.-J., and E. J. Brown. 1994. CR3 (Mac-1, $\alpha_{M} \beta_{2}$, CD11b/CD18) and $\mathrm{Fc} \gamma \mathrm{RIII}$ cooperate in generation of a neutrophil respiratory burst: requirement for Fc $\gamma$ RII and tyrosine phosphorylation. J. Cell Biol. 125:1407-1416.

62. Guinec, N., V. Dalet-Fumeron, and M. Pagano. 1993. "In vitro" study of basement membrane degradation by the cysteine proteinases, cathepsin B, B-like and L. Biol. Chem. Hoppe-Seyler. 374:1135-1146.

63. Chapman, H. A., J. J. Reilly, and L. Kobzik. 1988. Role of plasminogen activator in degradation of extracellular matrix protein by live human alveolar macrophages. Am. Rev. Respir. Dis. 137:412-419.

64. Matrisian, L. M. 1992. The matrix-degrading metalloproteinases. Bioessays. $14: 455-463$

65. Kobayashi, H., N. Moniwa, M. Sugimura, H. Shinohara, H. Ohi, and T. Terao. 1993. Effects of membrane-associated cathepsin B on the activation of receptor-bound prourokinase and subsequent invasion of reconstituted basement membranes. Biochim. Biophys. Acta. 1178:55-62.

66. Mignatti, P., and D. B. Rifkin. 1993. Biology and biochemistry of proteinases in tumor invasion. Physiol. Review. 73:161-194.

67. Ossowski, L., and E. Reich. 1983. Antibodies to plasminogen activator inhibit human tumor metastasis. Cell. 35:611-619.

68. Ossowski, L. 1988. In vivo invasion of modified chorioallantoic membrane by tumor cells: the role of cell surface-bound urokinase. J. Cell Biol. 107:24372445.

69. Damsky, C. H., and Z. Werb. 1992. Signal transduction by integrin receptors for extracellular matrix: cooperative processing of extracellular information Curr. Opin. Cell Biol. 4:772-781.

70. Fibbi, G., M. Ziche, L. Morbidelli, L. Magnelli, and M. Del-Rosso. 1988 Interaction of urokinase with specific receptors stimulates mobilization of bovine adrenal capillary endothelial cells. Exp. Cell Res. 179:385-395.

71. Gyetko, M. R., R. F. Todd, C. C. Wilkinson, and R. G. Sitrin. 1994. The urokinase receptor is required for human monocyte chemotaxis in vitro. J. Clin Invest. 93:1380-1387.

72. Ploug, M., T. Plesner, E. Ronne, V. Ellis, G. Hoyer-Hansen, N. E. Hansen, and K. Dano. 1992. The receptor for urokinase-type plasminogen activator is deficient on peripheral blood leukocytes in patients with paroxysmal nocturnal hemoglobinuria. Blood. 79:1447-1455.

73. Yeh, E. T. H., and W. F. Rosse. 1994. Paroxysmal nocturnal hemoglobinuria and the glycosylphosphatidylinositol anchor. J. Clin. Invest. 93:2305-2310. 